\title{
KREATIVITAS DALAM PEMBUATAN ARANSEMEN MUSIK SEKOLAH
}

\author{
Heni Kusumawati \\ Jurusan Pendidikan Seni Musik, FBS, Universitas Negeri Yogyakarta \\ E-mail: heni_kusumawati@uny.ac.id
}

\begin{abstract}
Abstrak
Kreativitas merupakan sarana untuk mengungkapkan ekspresi, imajinasi dan apresiasi dalam bermusik. Salah satu kegiatan pembelajaran seni budaya/seni musik adalah mengekspresikan diri melalui karya seni dengan pembuatan aransemen musik sekolah. Aransemen merupakan kegiatan kreatif dalam mengolah dan mengembangkan elemen-elemen musik menjadi sebuah karya baru. Adapun tahapan dalam pembuatan aransemen sederhana untuk musik sekolah diantaranya adalah: 1) Menentukan lagu yang akan di aransemen, 2) Mengolah pola ritme/harga nada/irama/durasi notasi, 3) Menentukan Akor, 4) Menulis melodi, 5) Progresi Akor (pergerakan akor), dan 6) Lintas sukat, sedangkan format instrumen yang akan diaransemen menyesuaikan dengan alat musik yang dimiliki sekolah sehingga format instrumen bisa berupa kuartet, kuintet atau ansambel.
\end{abstract}

Kata kunci: kreativitas, aransemen musik sekolah, format instrumen.

\section{THE CREATIVITY IN COMPOSING SCHOOL MUSIC ARRANGEMENT}

\begin{abstract}
Creativity is a way of expressing ideas, imagination, and appreciation in music. One of the activities in the learning of music is expressing oneself through the work of art by composing school music arrangement. Music arranging is a kind of creative activity in managing and developing musical elements to become a new work. The steps taken in composing a simple music arrangement were: 1) determining the song which will be arranged, 2) managing the patterns of rythm/ tone/ rhyme/ notation duration, 3) determining the musical accord, 4) writing the melody, 5) progressing accord, and 6) Lintas sukat, while the instrument format was adjusted to the musical instruments in the school, so it can be in the form of quartet, quintet, or ensemble.
\end{abstract}

Keywords: creativity, school music arrangement, instrument format 


\section{PENDAHULUAN}

Pembelajaran seni musik di sekolah merupakan salah satu sarana mengungkapkan ekspresi, imajinasi, kreativitas dan apresiasi karya musik. Dengan belajar musik anak-anak berlatih bersosial dalam hidup, hal ini dapat diaplikasikan pada saat penyajian musik ansambel dimana semua anggota harus dapat bekerja sama, saling menghargai dan disiplin. Hal ini seperti dikemukakan oleh Rien (1991), bahwa seni musik mempunyai peranan yang penting dalam kehidupan seorang siswa. Selain dapat mengembangkan kreativitas, musik juga dapat membantu perkembangan individu, mengembangkan sensitivitas, membangun rasa keindahan, mengungkapkan ekspresi, memberikan tantangan, melatih disiplin dan mengenal sejarah budaya bangsa.

Pelajaran musik di sekolah sebenarnya bukanlah mengajari bagaimana cara memainkan alat musik melainkan pelajaran dasar bermain musik dengan menggunakan alat-alat sederhana seperti pianika, recorder dan gitar, karena tujuan dari pelajaran musik itu sendiri semata-mata hanya sebagai pengetahuan dasar dalam praktek bermain instrumen musik bukan menciptakan seniman yang ahli dalam bermain musik. Pelajaran musik di sekolah hanya memberi pemahaman tentang pengetahuan dasar musik (teori musik) melalui kegiatan-kegiatan seperti mendengar, menirukan dan menyanyikan nada, melodi dan ritme (sofegio), baik menggunakan alat musik maupun dengan vocal.

Pelaksanaan pembelajaran seni musik pada umumnya menggunakan metode ceramah dan drill, namun metode ini dirasa masih perlu dikembangkan karena pembelajaran musik di sekolah tidak hanya menguasai ketrampilan bermusik dan olah vokal, namun diharapkan dapat mengembangkan kemampuan kritis, apresiatif, kreatif, imajinatif, dan inovatif, sehingga siswa dapat mengeksplorasi imajinasi mereka melalui karya-karya yang dibuatnya (Utomo, 2013). Pembelajaran seni melibatkan semua bentuk kegiatan berupa aktivitas fisik dan cita rasa keindahan yang tertuang dalam kegiatan berekspresi, bereksplorasi, berapresiasi dan berkreasi melalui bahasa rupa, bunyi, gerak dan peran (seni rupa,musik, tari, dan teater). Masing-masing mencakup materi sesuai dengan bidang seni dan aktivitas dalam gagasan-gagasan seni, keterampilan berkarya seni serta berapresiasi dengan memperhatikan konteks sosial budaya masyarakat (Diknas, 2003). 
Peranan guru seni musik dalam hal ini sangat penting, karena guru harus dapat membangkitkan daya apresiasi musik sehingga siswa dapat mengenal berbagai macam genre musik melalui contoh-contoh lagu yang digunakan sebagai penunjang pembelajaran. Persoalan yang ada sekarang adalah kompetensi yang dimiliki guru-guru seni budaya tidak selalu sesuai dengan bidang keahliannya. Sebagai contoh guru seni rupa tetapi juga dituntut untuk mengajar seni musik atau seni tari, demikian juga sebaliknya. Pengembangan kompetensi guru dalam hal ini sangat penting karena guru dituntut profesional, sehingga guru harus dapat mengembangkan kompetensinya khususnya di bidang seni budaya.

Salah satu kegiatan pembelajaran seni budaya/seni musik yang tertuang dalam standar kompetensi adalah mengekspresikan diri melalui karya seni, sedangkan kompetensi dasarnya adalah mengaransir secara sederhana karya lagu daerah setempat. Untuk dapat membuat aransemen musik sederhana diperlukan pengetahuan dasar musik dan kreatifitas dalam mengolah melodi, ritmis dan harmoni yang ada dalam lagu yang akan diaransemen.

Materi pokok dalam mata pelajaran seni musik di SMP adalah musik ansambel dan vokal grup sedangkan kegiatan belajar yang dilakukan diantaranya adalah membuat aransemen sederhana lagu daerah baik untuk vokal maupun instrumen, dengan menentukan pembagian suara dalam vokal dan membagi iringan dalam kelompok musik.

Adapun tujuan dalam bermain musik ansambel dan vokal grup adalah mengajarkan siswa untuk berlatih bekerja sama (cooperatif Learning), karena permainan ansambel dan vokal grup melibatkan beberapa pemain yang menuntut kerjasama yang baik antar individu dalam satu kelompok. Dengan bermain ansambel diharapkan siswa menjadi lebih disiplin, sportif, toleransi, peka dan peduli pada lingkungan di sekelilingnya.

\section{MEMBUAT ARANSEMEN SEDERHANA}

Aransemen merupakan kegiatan kreatif dalam mengolah dan mengembangkan elemen-elemen musik menjadi sebuah karya baru. Menurut Munandar (1995), kreativitas adalah suatu kemampuan umum untuk menciptakan suatu yang baru, sebagai kemampuan untuk memberikan gagasan-gagasan baru 
yang dapat diterapkan dalam pemecahan masalah atau sebagai kemampuan untuk melihat hubungan-hubungan baru antara unsur-unsur yang sudah ada sebelumnya.

Di dalam aransemen ada proses penciptaan, sebab musik yang akan ditata adalah bahan dasar sedangkan musik yang telah ditata harus mengandung nilai plus secara menyeluruh baik pada akor (harmoni iringan), filler, maupun kontra melodinya akan tercipta dari penentuan akor yang total dan maksimal. Menentukan akor juga bukan pekerjaan matematis yang kaku namun perlu ngeng yang dapat mencapai titik interest pada setiap pendengar dan penikmatnya.

Berikut ini akan dibahas secara singkat tentang langkah-langkah pembuatan aransemen untuk vocal dan ansambel. Beberapa tahapan dalam membuat aransemen untuk vokal grup dan ansambel adalah sebagai berikut (Kusumawati, 2006):

\section{Menentukan lagu yang akan diaransemen.}

Pemilihan lagu disesuaikan dengan tema atau materi pembelajaran sesuai dengan KI dan KD yang terdapat dalam kurikulum 2013, misalnya lagu daerah, lagu nasional dan lagu popular. Peran guru di sini sangat penting dalam menentukan pilihan lagu-lagu yang akan di aransemen.

Tugas guru adalah memberikan alternatif pilihan lagu-lagu yang akan di aransemen baik lagu daerah, nasional maupun populer yang memiliki tingkat kesulitan yang sama. Alangkah baiknya jika lagu-lagu yang dipilih juga mengandung pesan-pesan moral yang sesuai dengan perkembangan usia anak-anak remaja pada khususnya, sehingga misi dan visi lagu-lagu tersebut dapat tersampaikan melalui syair lagu yang akan di aransemen.

\section{Mengolah pola ritme/harga nada/irama/durasi notasi}

Ritme dari lagu yang akan diaransemen dapat dikembangkan dengan mengolah harga nadanya menjadi lebih pendek atau lebih panjang tergantung dari tanda sukat/birama pada lagu yang akan diaransemen. Lagu bertanda sukat 3/4 tentu berbeda dengan lagu bersukat 4/4, karena lagu bersukat $3 / 4$ biasanya berirama waltz. Contoh pola ritme lagu bersukat 4/4: 


\section{YESTERDAY}

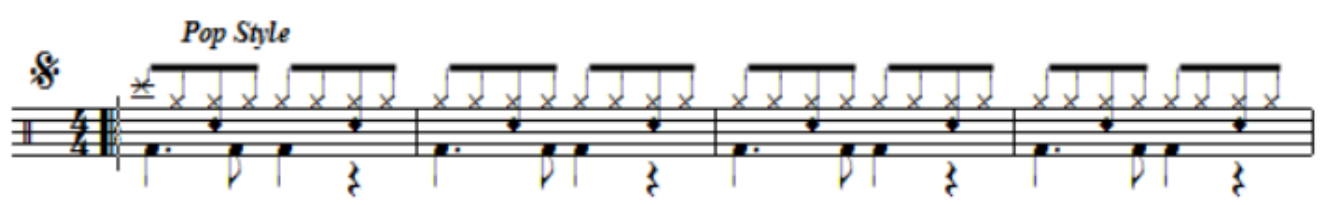

Contoh pola ritme lagu bersukat 3/4 yang kemudian di tengah-tengah lagu berubah menjadi 4/4:

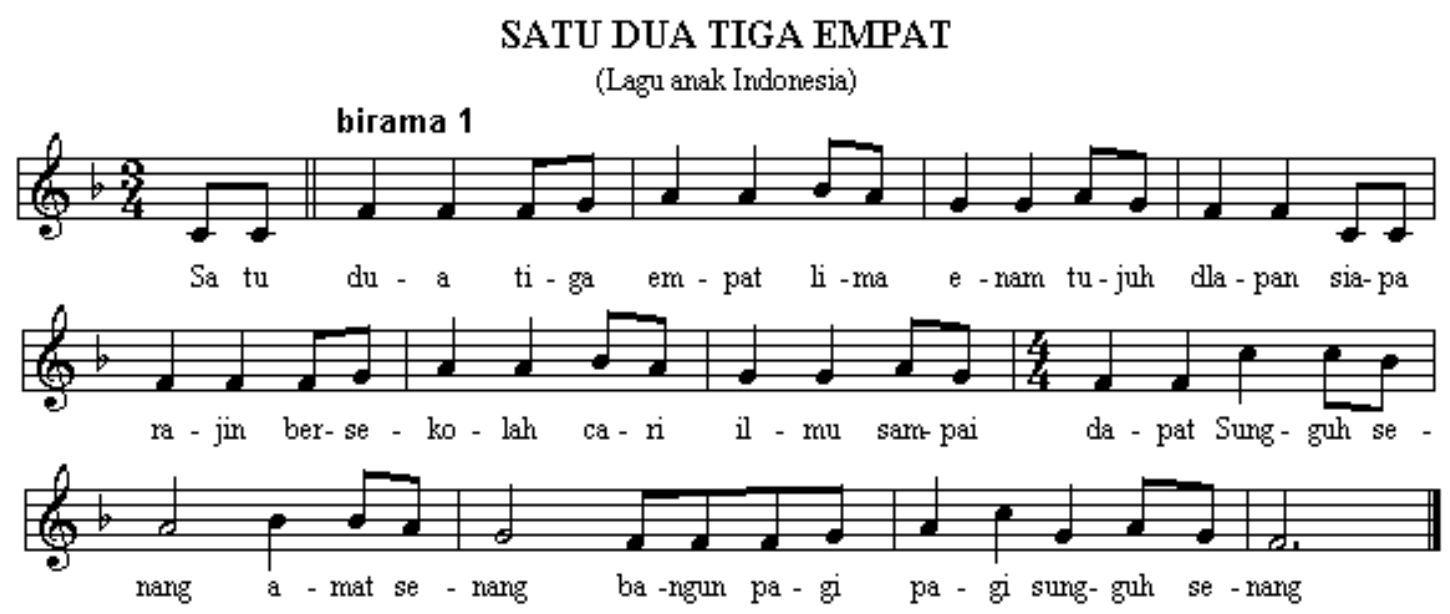

Secara struktur lagu yang berjudul Satu Dua Tiga Empat pada birama 1 sampai dengan birama 7 bersukat 3/4, namun pada birama 8 sampai dengan birama 11 sukatnya menjadi 4/4. Apa yang terjadi seandainya seluruh lagu tersebut menggunakan sukat 3/4 untuk semua birama? Lagu tersebut akan terasa janggal.

Menentukan sukat dan metrum pada suatu pola ritme sebuah lagu dapat dilakukan dengan jalan memainkan lagu tersebut terlebih dahulu secara utuh, kemudian dalam proses penulisannya berdasarkan pada titik penting (important period), yaitu menandai atau menengarai saat jatuhnya akord dengan simbol aksen. Contohnya apabila lagu bersukat 2/4 dan akhirnya tertulis menjadi 4/4 itu tidaklah masalah karena penyelesaiannya masih familier, meskipun secara prinsip antara sukat 2/4 dengan 4/4 sangat berbeda sifatnya.

\section{Menulis melodi}

Melodi sangat erat hubungannya dengan pola ritme karena di dalamnya terdapat unsur pola ritme. Dalam melodi juga terdapat pitch (tinggi rendah) nada dan lompatan-lompatan nada (intervals). Melodi yang dinamis artinya hidup. Sedangkan gerakan-gerakan melodi dapat tetap, naik, dan turun. 
Melodi adalah bagian yang penting dalam proses aransemen, karena dari melodi tersebut dapat dikembangkan menjadi suara 2, 3 atau lebih berdasarkan progresi akor dari lagu yang akan di aransemen. Lagu di berikut ini menunjukkan bahwa vocal 1 menyanyikan lagu pokok, sedangkan vokal 2 dan 3 menjadi filler atau pengisi untuk memperindah lagu, hal ini dibuat agar tidak terkesan monoton sehingga dibuat bersahut-sahutan. Seperti terlihat pada lagu berikut ini:

\section{Ampar ampar Pisang}

(lagu daerah Kalimantan Selatan)
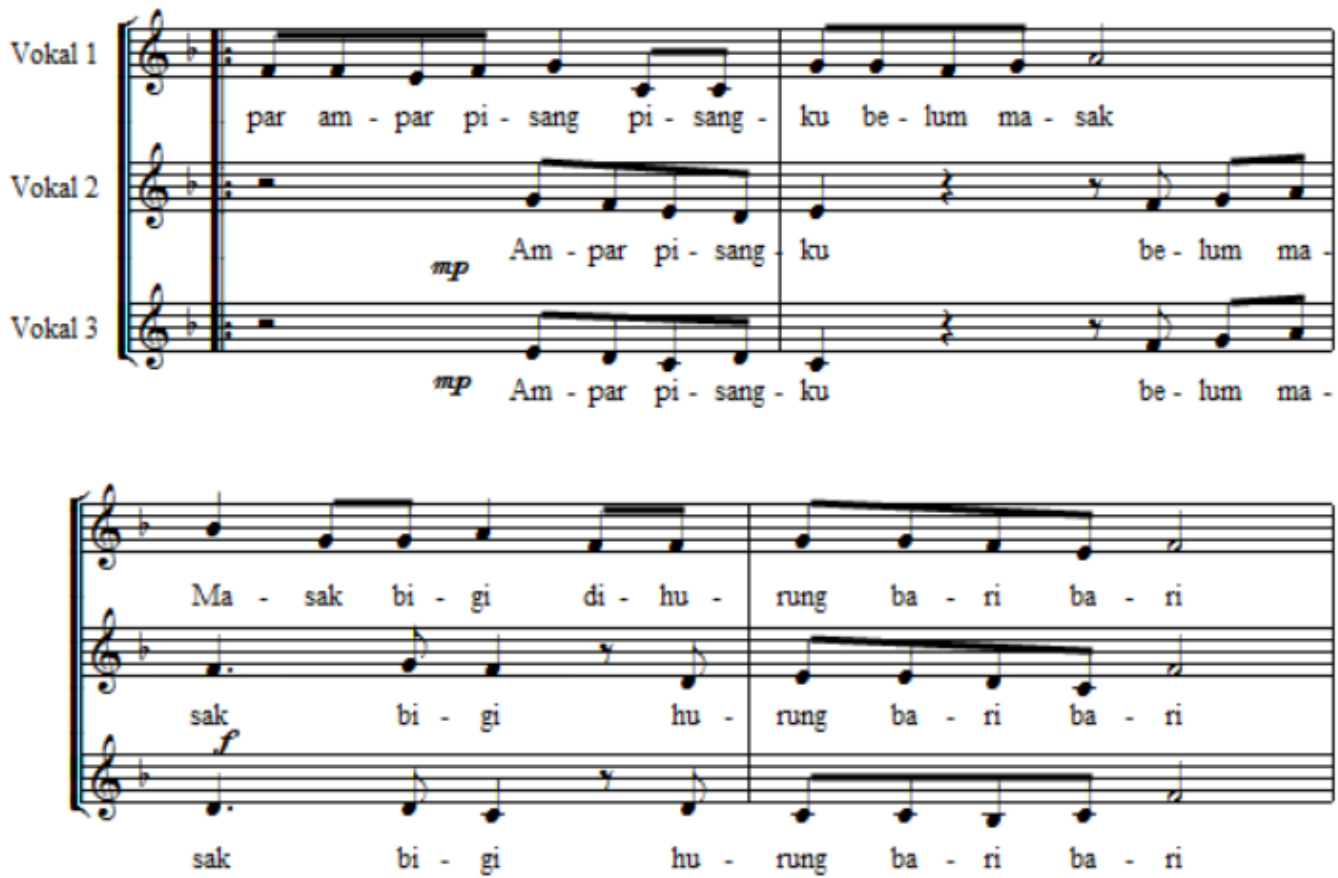

\section{Menentukan Akor}

Menentukan akor iringan sebenarnya tidak rumit sebab ada banyak cara/sistem yang dapat digunakan untuk menentukan akor. Akor bisa ditentukan dari unsur-unsur melodi yang ada pada tiap-tiap birama. Seperti terlihat pada potongan melodi di bawah ini. Pada birama 1 unsur nada yang dominan adalah akor I karena mengandung nada 35 i. Sedangkan progresi akor yang digunakan adalah C - G/B - am dan seterusnya. 


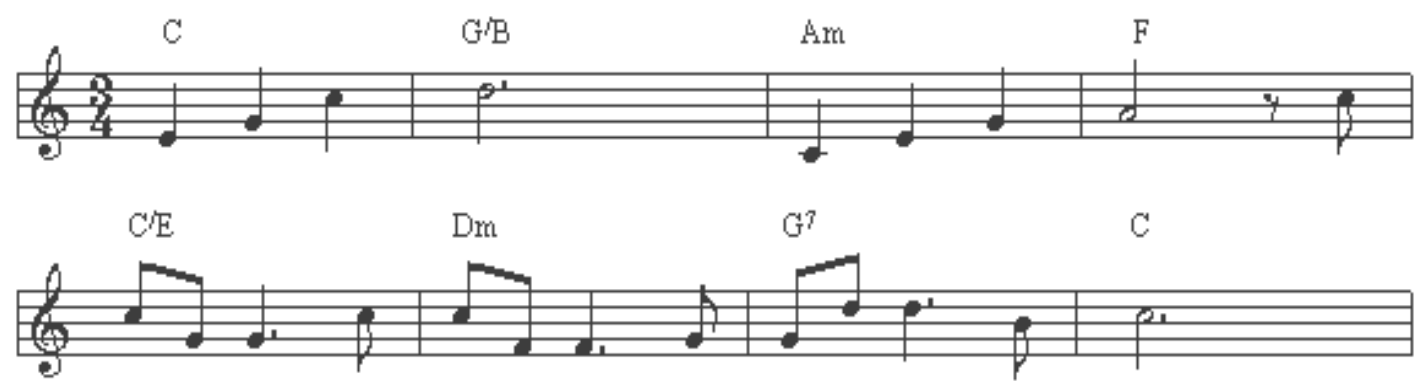

Menentukan akor pada suatu melodi sebenarnya mudah dipahami dengan melihat sifat-sifat melodi yang bersangkutan, misalkan not 1 (do) diikuti dengan nada 2 (re), 3 (mi), 4 (fa), 5 (sol) dan 6 (la) maka bila nada 1 (do) bersebelahan dengan 2 (re) dan 3 (mi) maka akor yang digunakan menjadi:

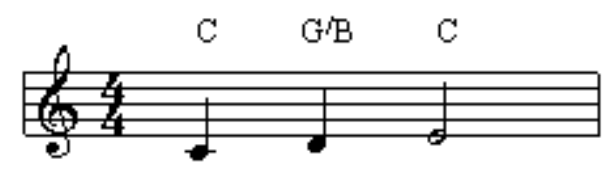

Dalam harmoni manual penekanan harmoni terletak pada accompaniment pattern atau harmoni iringan, maka setiap ketuk melodi diberi akor sebagai iringannya. Harmoni iringan dengan system blok akor untuk mengiringi melodi do, re, dan mi maka akor yang digunakan di atas cukup $\mathrm{C}$ mayor saja. Bila rangkaian melodi itu kita gabung maka penempatan akor pada melodi tersebut kelihatan kaku dan baku karena mengacu pada progresi akor klasik seperti terlihat pada contoh berikut ini:

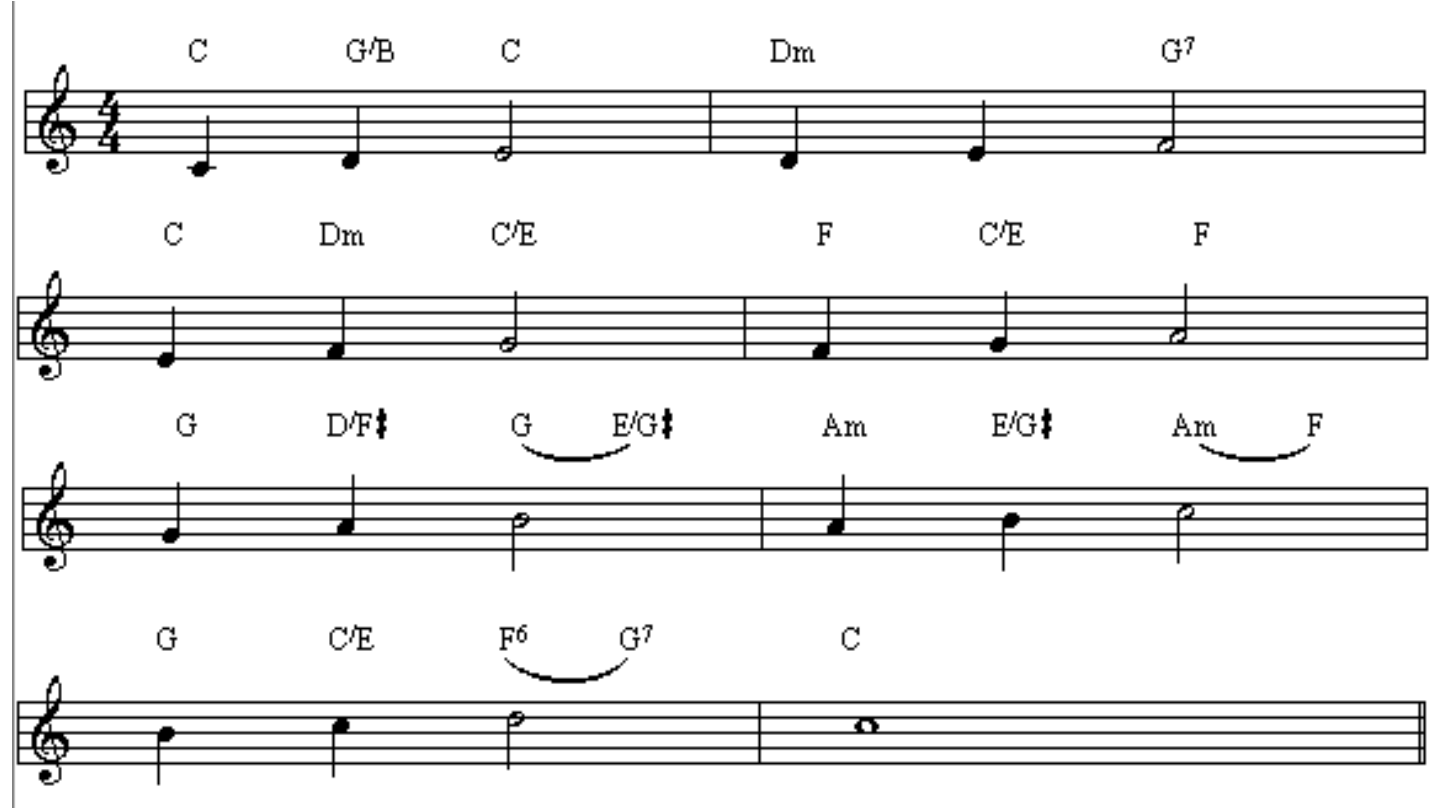




\section{Progresi Akor (pergerakan akor)}

Pergerakan akor dalam sebuah lagu ditentukan oleh alur melodi yang membentuk rangkaian akor. Progresi akor terbentuk berdasarkan tingkatannya. Dalam tingkatan akor dikenal akor Mayor dan akor minor. Akor I, IV dan V disebut akor Mayor, sedangkan akor ii, iii dan vi disebut akor minor. Progresi akor bisa berupa akor mayor semua namun bisa juga campuran mayor dan minor. Contoh progresi akor yang sering digunakan dalam lagu adalah sebagai berikut:
a. I - IV - I
b. I - V - I
c. I - IV - I -V - I
d. I - vi - ii - V - I - IV - I

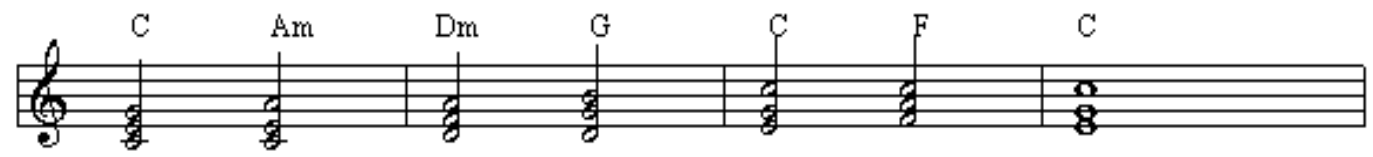

e. I - iii - vi - ii - V - I

f. I - IV - ii - V - iii - vi -ii -V - I

g. I - iii - IV - ii - V - I dll.

Untuk membuat progresi akor yang indah sebaiknya tidak hanya dibatasi dengan penggunaan akor-akor dasar, melainkan juga mencoba menerapkan akorakor yang progresif, misalnya dengan menggunakan akor pembalikan (inversi) I, II dan III supaya terkesan lebih dinamis dan manis. Contoh progresi akor pada lagu Kupu-kupu Kemana Engkau Terbang: 


\section{KUPU-KUPU KEMANA ENGKAU TERBANG}

(Cipt. Iou Sud)

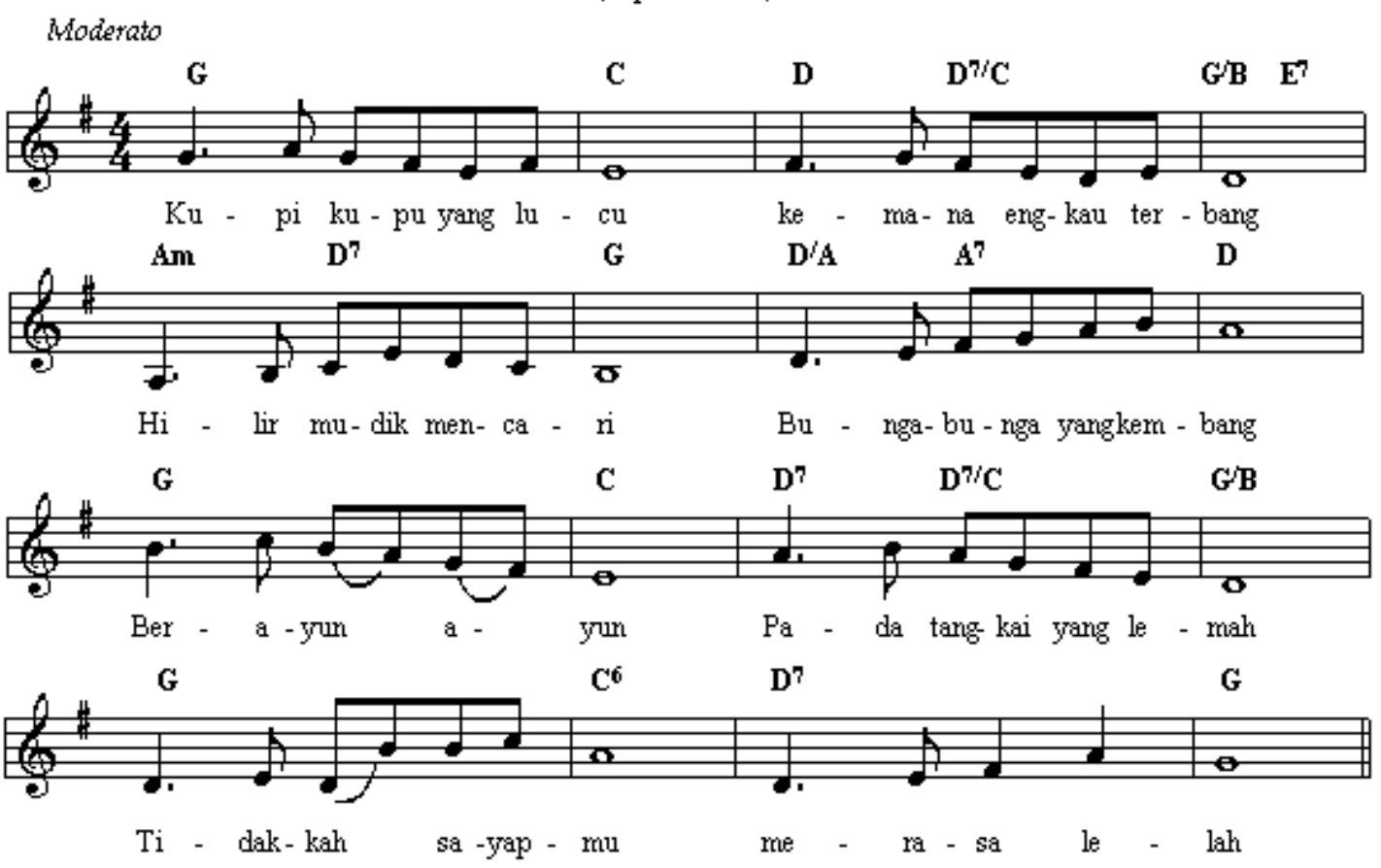

Proses merencanakan akor-akor mana yang tepat untuk mengiringi sebuah melodi sama halnya dengan membuat konsep arrangement (penataan) musik, jadi apabila hasilnya terdengar lebih baik dibanding sebelumnya berarti aransemennya berhasil. Sebaliknya kalau hasil dari penataan tersebut menjadi kurang baik, maka proses penataan musik dianggap tidak berhasil. Pada dasarnya aransemen musik secara umum membuat musik lebih hidup dan lebih progresif serta lebih memikat dari materi aslinya.

\section{Lintas Sukat}

Salah satu pengembangan aransemen yang berikutnya adalah dengan cara lintas sukat. Lintas sukat dapat dilakukan dengan merubah posisi lagu yang awalnya bersukat 4/4 menjadi 3/4 atau sebaliknya. Namun tidak semua lagu bisa di buat lintas sukat karena kalau tetap dipaksakan akan menjadi janggal. Salah satu lagu yang bisa lintas sukat diantaranya adalah lagu Burung Kaka Tua. 


\section{BURUNG KAKA TUA}

(Sukat \& Metrum aslinya)

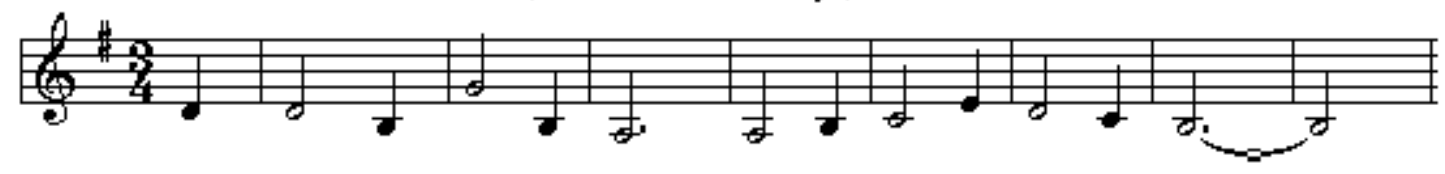

Lagu di atas adalah versi yang asli dalam sukat 3/4, namun lagu tersebut juga bisa dibawakan dengan versi lain yaitu versi 4/4 dengan irama beguine.

\section{BURUNG KAKA TUA}

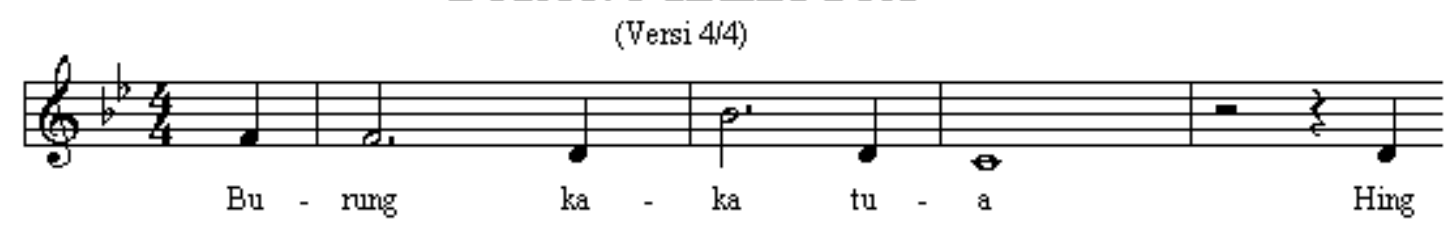

Dengan berubahnya sukat dan metrum maka akan berubah juga sifat dan karakternya, namun apabila lagu tersebut termasuk dalam katagori lagu-lagu yang lintas sukat, maka tidak akan terjadi kejanggalan. Contoh lagu lain yang termasuk lintas sukat adalah $\mathrm{O}$ Ina $\mathrm{Ni}$ Keke.

Sebagai pedoman "Sebuah melodi yang sudah mapan atau dalam keadaan stabil baik sukat maupun metrumnya akan menjadi janggal bila sukatnya dirubah, kecuali dengan cara merubah pola ritmenya". Apabila proses perubahan tetap dilakukan maka melodi akan menjadi lagu yang lain

\section{FORMAT INSTRUEMEN}

Format instrumen merupakan susunan alat-alat musik dalam kelompok ansambel yang akan digunakan sebagai alat ekspresi musikal siswa. Biasanya format instrumen ansambel menyesuaikan dengan alat musik yang dimiliki sekolah, sehingga format ansambel satu sekolah dengan yang lainnya tidak sama. Artinya format instrumennya tidak harus standard tetapi menyesuaikan dengan kondisi sekolah.

Format instrumen untuk ansambel bisa sejenis atau campuran. Sebagai contoh ansambel strings terdiri dari biola 1, biola 2, biola alto dan Cello. Sedangkan ansambel campuran terdiri dari recorder, pianika, biola, keyboard dan perkusi. Namun demikian format ansambel untuk SMP masih bisa dikembangkan lagi sesuai dengan instrumen yang ada di sekolah. Contoh ansambel campuran: 


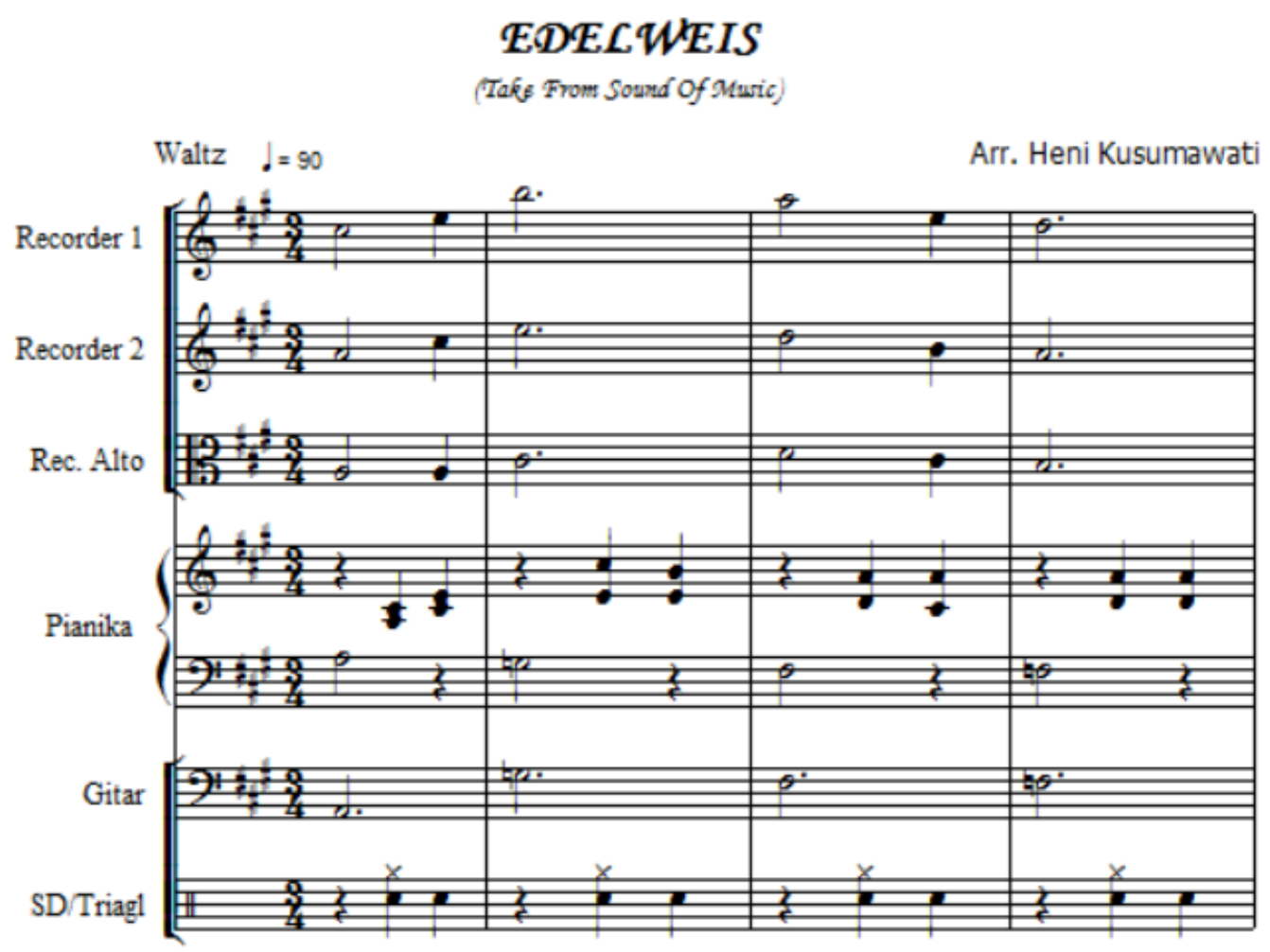

\section{KESIMPULAN}

Mengembangkan kreativitas melalui kegiatan bermusik merupakan bagian dari produk kreatif, dimana anak diberi keleluasaan untuk membuat pembaruan (inovasi) dan pengembangan (evolusi) dari karya musik yang diciptakan melalui kegiatan mengaransemen lagu sederhana. Melalui pembelajaran aransemen siswa dapat mengeksplorasi ide-ide musikalnya melalui karya-karya baru yang dibuatnya.

Peran guru sebagai mediator khususnya mata pelajaran seni musik diharapkan dapat menambah apresiasi dan wawasan siswa dengan mengenalkan karya-karya musik yang sesuai dengan perkembangan jiwa anak-anak, sehingga pembelajaran musik khususnya materi aransemen menjadi mata pelajaran yang menyenangkan dan mesiswa lebih kreatif dalam menuangkan ide-ide musikalnya. 


\section{DAFTAR PUSTAKA}

Depdiknas. 2003. Sistem Pendidikan Nasional. Jakarta: Depdiknas

Kusumawati, Heni. 2006. Komposisi. Diktat (tidak diterbitkan). Yogyakarta: FBS UNY

Munandar, Utami. 1999. Pengembangan Kreativitas Anak Berbakat. Jakarta: Depdiknas.

Safriena, Rien. 1999. Pendidikan Seni Musik. Jakarta. TP

Utomo, Udi . 2013.”Analisis Kebutuhan Guru Seni Musik Dalam Konteks Pelaksanaan PembelajaranBerbasis Action Learning Di Sekolah".

Harmonia, Jurnal Pengetahuan dan Pemikiran Seni, Vol. 13, no. 2 